\title{
Case report: \\ UPPER LIP RECONSTRUCTION AFTER LIP CANCER WIDE EXCISION
}

\author{
Boedy Setya Santoso, Citra Dwi Novastuti \\ Department of Otorhinolaryngology Head and Neck Surgery, Faculty of Medicine, Universitas Airlangga, Dr. Soetomo \\ Hospital, Surabaya, Indonesia
}

\section{ABSTRACT}

Foreign objects may be present in the bladder due to deliberate insertion or displacement of the surrounding organs. There have been multiple cases of sharp objects such as nails, hair pins, and screws, as well as large objects such as AAA batteries, toothbrushes, and ballpoint pens found in the urethra and the bladder, which must have been aimed to induce sexual satisfaction associated with mental and psychic disorders. The diagnosis was established by means of radiological examinations, ie thoracic $x$ ray, KUB, and urethrography. This article reported a 32-year-old man with headset inserted to penile until bladder and could not be pulled out again. The patient complained pain and bleeding out of the urinary tract. We performed vesicotomy and pulling the out headset from bladder. The operation was succesful. In conclusion, the case of a headset in the bladder has been treated successfully with vesicotomy.

Keywords: Headset in bladder; vesicotomy

\section{ABSTRAK}

Rekonstruksi kepala dan leher memiliki dua tujuan yaitu mengembalikan fungsi dan estetika. Prioritas tujuan rekonstruksi bibir harus ditentukan sebelum operasi. Dalam kasus cacat bibir yang lebar, mempertahankan tujuannya membuat rekonstruksi bibir menjadi sulit. Ini adalah laporan kasus seorang pria berusia 66 tahun yang datang ke ORL-HNS OPD, Rumah Sakit Dr. Soetomo, Surabaya dengan keluhan utama ulkus di bibir atas sejak satu tahun yang lalu disertai dengan rasa sakit. Hasil biopsi massa pada vestibulum kanan di Malang pada 11 Oktober 2016 menunjukkan adeno squamous cell carcinoma. Pasien berencana melakukan eksisi luas dan rekonstruksi cacat bibir. Eksisi luas dan rekonstruksi bibir dilakukan pada 15 September 2016. Reseksi total bibir atas dilakukan hingga vestibulum hidung. Hasil penelitian menunjukkan bahwa karsinoma sel skuamosa berdiferensiasi buruk. Evaluasi setelah operasi flap miokutan bergabung dengan baik, tidak ada tanda-tanda peradangan atau infeksi. Pasien bisa membuka mulut, makan, minum, dan berbicara tanpa keluhan. Pasien kemudian dilakukan kemoradioterapi secara rutin dua minggu setelah operasi.

Kata kunci: Rekonstruksi bibir atas; kanker bibir; eksisi luas

\section{Correspondence:}

pISSN:2355-8393 • eISSN: 2599-056x • doi: http://dx.doi.org/10.20473/fmi.v55i2.14349

- Fol Med Indones. 2019;55:147-152 • Received 10 May 2017 Accepted 23 Nov 2017

- Open access under CC-BY-NC-SA license • Available at https://e-journal.unair.ac.id/FMI/

\section{INTRODUCTION}

Reconstruction of the head and neck differs from reconstruction in any other region in the body has the dual purpose of restoring function and aesthetics. Lips are one organ for which aesthetic and functional considerations are equally important for successful outcome. The ideal lips reconstruction procedure is to maintain lips sensation, sphincter and muscle that can prevent drooling, open mouth to enter food, maintain denture, oral hygiene, expresif components and esthetically accepted (Puscas et al 2014). In many cases, not all of the purposes are achieved. Therefore, priority of lip reconstruction purpose must be determined before surgery. In a case of wide lip defect, maintaining the purpose makes lips reconstruction challenging.

The main etiology of acquired lips defect is cancer. Prevalence of lower lip defect is $96 \%$, suspected due to long term sunlight exposure. Types of dominant tumor cell is squamous cell $(96 \%)$, followed by basal cell ca, verrucous carcinoma, and adenocarcinoma (Salibian \& Urken 2014). The lips cancer found most in males (97\%), whereas upper lip cancer found more often in females than males (20\%:4\%) (Salibian \& Urken 2014). In management of lips cancer, lips reconstruction is 
stage that can not be separated. Previous literature more discuss about lower lip reconstruction (Matros \& Pribaz 2014). This can be caused by higher incidence of malignancy at lower lip than upper lip and gravity effect that affect the lower lip integrity (Matros \& Pribaz 2014).

There are various techniques of lips reconstruction have been applied that no single methode has emerged as the accepted standard. The surgeon sometimes found difficulty in determining which technique apllied to one case. The main consideration in determining lips reconstruction technique is the extensive of defect. Upper and lower lips have differences in topography and functions. The surgeon should understand about basic principle and the range of surgical options for restoring perioral region. Understanding the subunits of the upper and lower lips as well as their anatomic boundaries is importanat to achieving a result that restores facial harmony.

One case reported in a male aged 66 years old with malinancy of upper lip. Wide excision and upper lip reconstruction had been done with myocutaneus flap from nasolabial and mentolabial fold. Reconstruction results showed optimum lips function.

\section{Case Report}

Male aged 66 years old came to ORL-HNS OPD Dr. Soetomo Hospital, Surabaya with chief complaint of ulcus on upper lip since one year ago accompanied with pain. Upper lip ulcus with irregular surface and sometimes bleeding. Patient is an active smoker for more than ten years. Patient general condition is fairly good with stable hemodynamic. From ORL-HNS examination, on upper lip there is ulcus with irregular border, easy to bleed (Fig 1). From anterior rhinoscopy examination there is mass on right vestibulum but none in nasal cavity. Examination of oral cavity there was no mass on alveolar mucosa, palatum not bombans. Patient referred from Dr. Syaiful Anwar general hospital Malang with vestibulum ulcus suspicious of basalioma.

Biopsy result of mass on right vestibulum at Malang on October 11th 2016 showed adeno squamous cell carcinoma. Patient planned to have wide excision and lip defect reconstruction. Physical examination patient, blood pressure was high, 200/110 $\mathrm{mmHg}$. Laboratory result was within normal limit and thorax photo result showed cardiothoracic-ratio (CTR) is $52 \%$ with pulmo within normal limit. Patient then consulted to cardiology department with the result Cardiac Risk Index Class (CRI) I with hypertension clinically without sign of acute decompensation cordis. Patient got therapy with nicardipine pump $0,5 \mu \mathrm{g} / \mathrm{Ig}$ until reach MAP $25 \%$ in the first 1 hour, then maintained with amlodipin $10 \mathrm{mg}$ once daily captopril $25 \mathrm{mg}$ three times daily. Patient got prophylaxis antibiotic with ceftriaxone 2 grams intravenously, one hour before surgery.

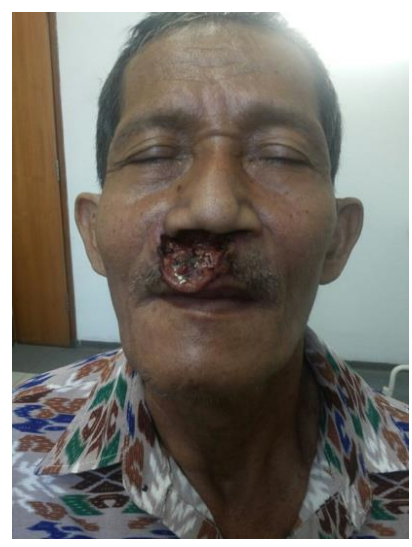

Fig 1. Ulcus on upper lip to right vestibulum, irregular surface, easy to bleed.

Wide excision and lips reconstruction was done at September 15th 2016. Total resection of upper lip was done until nasal vestibulum. Anterior part of septal cartilage excised then performed frozen section examination (Fig 2). Upper lip reconstruction was done using flap from bilateral nasolabial and mentolabial fold then sutured layer by layer (Fig 3). Patient was inserted nasogastric tube (NGT) for intake during wound healing. Post surgery patient conducted monitoring airway and sign of bleeding. During inpatient care, patient got antibiotic with ceftriaxone 1 gram every 12 hours intravenously, tranexamic acid $500 \mathrm{mg}$ every 8 hours intravenously, metamizole 1 gram every 8 hours intravenously and paracetamol drip $500 \mathrm{mg}$ every 8 hours intravenously.

Histopathologic examination result showed malignant growth consist of anaplastic epithelial cells proliferation with round-oval nucleus, pleiomorphic, hyperchromatic, prominent core nucleus, invasively grows into stroma, forms a honeycomb structure. The conclusion is squamous cell carcinoma, poorly differentiated.

Evaluation on the first day post surgery, operation sutures was merged in well with minimal swelling. (Fig 4A). On the second day, swollen between sutures was decreased (Fig 4B). On the third day, NGT was pulled out and patient was given liquid and soft intake with milk and pouridge. On the fifth day patient was discharged with therapy antibiotic clindamycine $150 \mathrm{mg}$ every 8 hours orally, gentamycin ointment for wound 
care and nasal rinse with physiologic fluid. One week after surgery patient controlled at ORL-HNS OPD, the sutures was removed, no sign of inflammation nor infection (Fig 5). Patient was then performed routinely chemoradiotherapy start from two weeks after surgery. Twelve months after surgery, patient was controlled, nos sign of residive mass. Patient can open his mouth, eat, drink, and talk without any complaint (Fig 6).
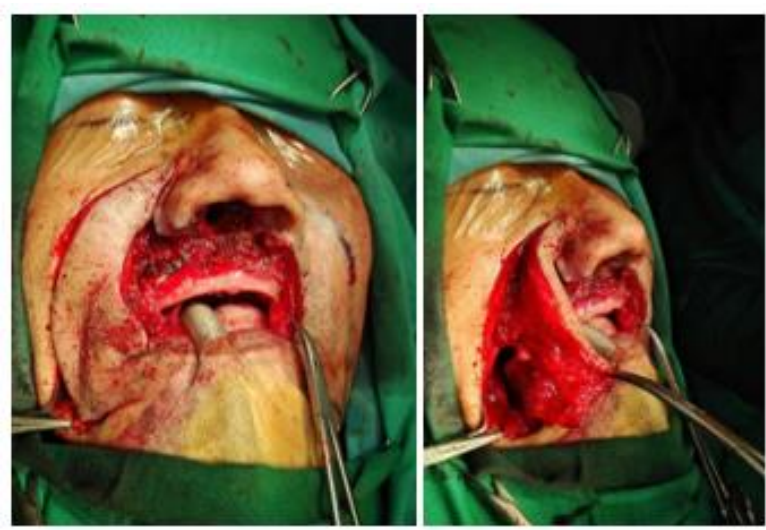

Fig 2. A. Wide excision, upper lip total resection until nasal vestibulum nasi B. Myocutaneous flap from bilateral nasolabial and mentolabial fold.

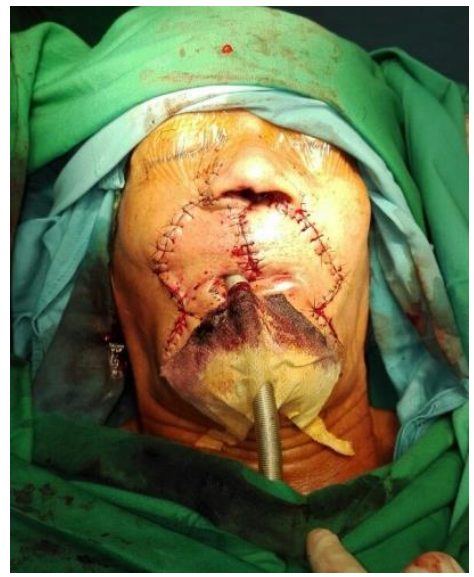

Fig 3. Flap from bilateral nasolabial and mentolabial fold covered defects on lip and nasal vestibulum, the sutured layer by layer.

\section{DISCUSSION}

Lip cancer in one of the most common malignancy in head and neck reigion with range of age at sixth until seventh decades. This malignancy most found in male, an active smoker and higher incidence at lower lip than uper lip. The most common histopathologic result is squamous cell carcinoma. Lip cancer manifestation is lesion or ulcus with irregular surface, easy to bleed, unhealed in several months to years. If this malignancy didn't cured well, tumor can be extended to superior until philtrum, nasal vestibulum and nasal alae. Extension to inferior until mentum, alveolar mucosa, until mandible (Puscas et al 2014). In this case, male aged 66 years old with ulcus on upper lip. Patient is an active smoker for more than 10 years. Patient complains lesion on upper lip unhealed since one year ago then became an ulcus. Ulcus on upper lip with irregular surface, easy to bleed, extended to nasal vestibulum. Histopathologic result was squamous cell carcinoma, poorly differentiated.

In managing lip cancer the main purpose are tumour eradication as well as maintaining lips function and esthethic through reconstruction. Understanding the lips functional anatomy, range of surgical option and lip reconstruction techniques are important to achieving a result that restores facial harmony (Puscas et al 2014). This case reported management of lip cancer with wide excision and lips reconstruction to achieve functional and esthetic purposes. The lips functional purpose that should be maintained are in chewing process, swallowing, prevent drooling, lips motion during expresing, and lips sensation toward touch, pain and temperature difference. The lips also important in articulation during speech process. Lip functional movements and sorrounding structures play an important role in daily activity such as eating, drinking, talking, and teeth brushing. Lips position, lips dynamical activity, upper and lower lip length, and lesion location are important to achieve maximal reconstruction result (Salibian \& Urken 2014).

Estimation of vermilion line while reconstruction is very important to prevent a step-off. Vermilion is a modified mucosa that coveres rounded free edge of the lip. Vermilion border is mucocutaneous junction, whereas posterior border is point of contact between upper and lower lip (Salibian \& Urken 2014). The upper lip has more defined boundaries than the lower lip, with the base of the nose and nasolabial folds. The nasolabial and mentolabial folds represents point of insertion of perioral muscles. The upper lip is also characterized by philtrum and the cupid's bow, which form elevation and depresion of the lips. Lesion around the mouth is best resected with insicion through this folds (Fig 7). Several undesired results are microstomia, asymmetrical lips, sutures that not merged in smaller flap, lips distortion or cheek duet to perioral muscle that not unify and abnormal contration, horizontal lesion on mentolabial folds and marionette's line, and also asymmetrical position of the commisure toward nasal lateral border. Horizontal lesion bilaterally and continued from nasolabial folds will form circular lesion around the lips (Fernandez 2015). In this case the lips cancer occured in upper lip extended to nasal vestibulum. Reconstruction 
with myocutaneous flap from bilateral nasolabial and mentolabial folds (Fig. 8).

The upper lip devided into three subunits, lateral and median. Two lateral subunits are bounded by philtrum, base of the nose, nasal sill, and the nasolabial folds. Median subunit from upper lip is bounded by philtra. The importance of this subunits are in covering lip defects according to those boundaries. The upper lip length in normal adult is $7 \mathrm{~cm}$ start from one side nasolabial fold to the other side, whereas the lower lip length is $8 \mathrm{~cm}$. Oral aperture is approximately $5 \mathrm{~cm}$ in length, start from commisure on the one side to the other dise. The maximal lip length while smiling or laughing is approximately $10 \mathrm{~cm}$. The distance between superior commisure to inferior of nasolabial folds is 1 until $1.5 \mathrm{~cm}$. In male adult, the defect on upper lip can be camouflaged by mustache. Anterior projection of the upper lip is bigger than the lower lip. Vegter et al founded the lip indeks, which is distance ratio between upper lip to tragus with lower lip to tragus. They found that the rasio is ranged between 0.97 until 0.99 in normal population (Salibian \& Urken 2014).

In several cases reported previously with good upper lip reconstruction result, Oseni et al using combination bilateral nasolabial flap with submental and buccal mucosa (Oseni et al 2015). Nishihara et al also reported upper lip reconstruction using advancement flap from cheek and buccal mucosal eversion (Nishihara et al 2016). Marcos et al reported defect reconstruction on the upper lip using bilteral revrse Yu flap (Marcos et al 2014). Cook also reported two cases defect reconstruction of the upper lip using bilateral nasolabial flap and cheek (Cook 2013). In this case reported wide excision of upper lip cancer that extended to nasal vestibulum causing full thickness defects with percentage $100 \%$ of upper lip vermillion. Reconstruction using advancement myocutaneous flap from nasolabial and mentolabial folds. Alveolar and upper teeth part still look good and didn't performed excision.

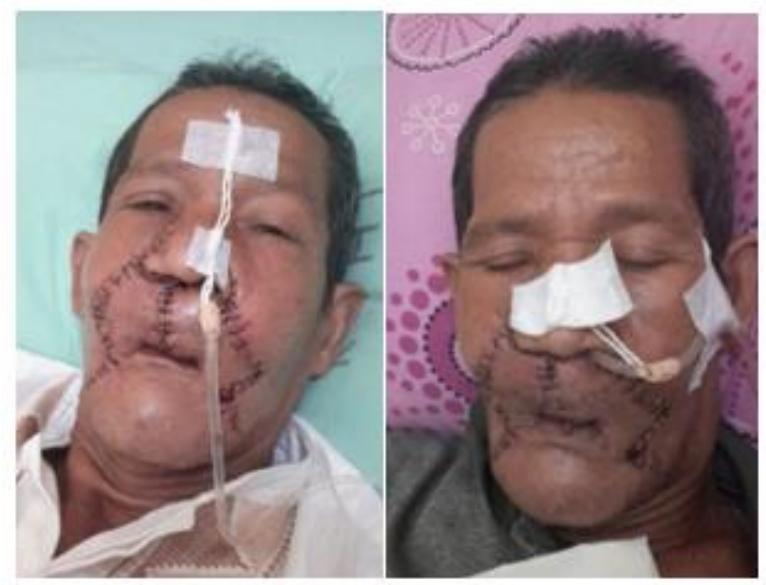

Fig 4. A. One day post surgery B. Two days post surgery.

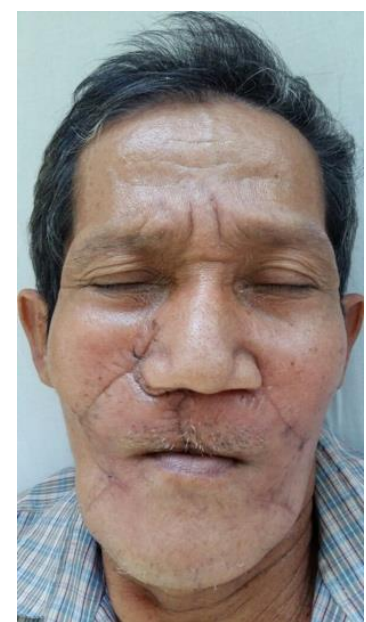

Fig 5. One week post surgery, the sutures was removed. 


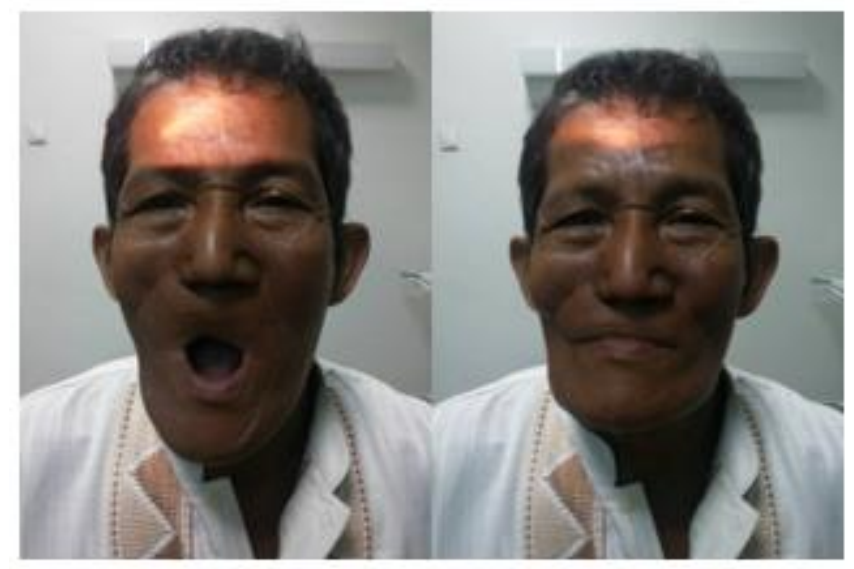

Fig 6. Twelve months after surgery
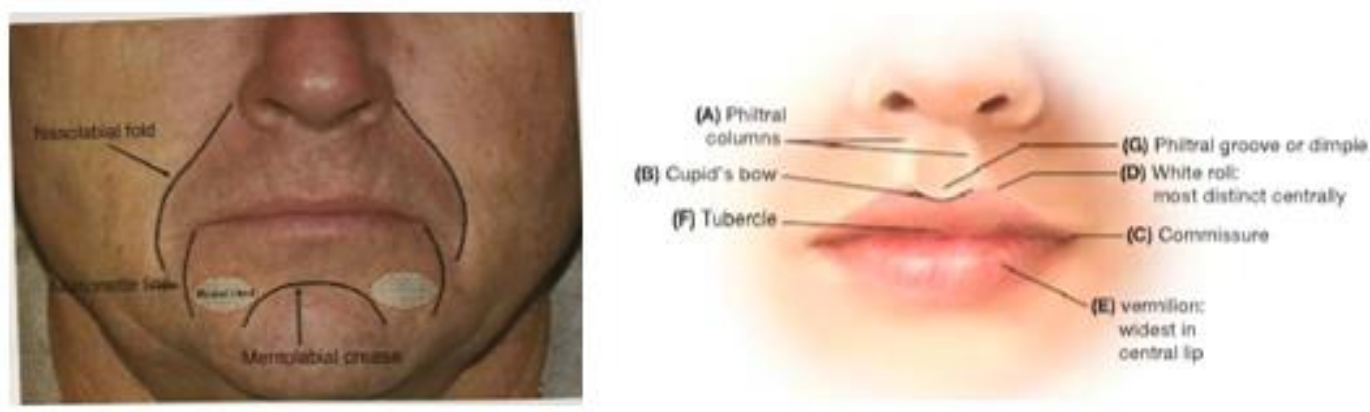

Fig 7. Upper and lower lips landmark2,3.

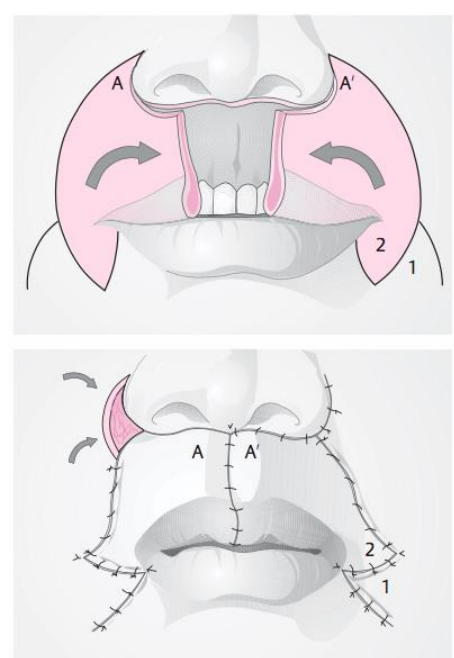

Fig 8. Bilateral nasolasial and mentolabial flap

In certain cases, a combination technique can be apllied in lip reconstruction, such as lower radial arm flap in total upper lip defects. To achieve similarity of skin color, a tissue expander can be used. The vermilion line can be lined with medical tattoing using fine needle and methylene blue (Puscas et al 2014, Salibian \& Urken 2014). In this case, flap from bilateral nasolabial after sutures removal was merged in well. Patient can open 
his mouth, eating, drinking, and talking without any complaint. Reconstruction result showed the nasal alar still look asymmteric and the upper lip looks thin and flattened. Esthetically, the reconstrction result can be maximixed with reconstruction of nasal alar in order to get symmetrical lips and medical tattoing to form vermilion. In this case the patient didn't performed advanced reconstruction surgery and then performed routinely chemoradiotherapy two weeks after surgery.

\section{CONCLUSION}

One case reported a male aged 66 years old with upper lip malignancy extended until nasal vestibulum. Patient was performed wide excision and lip reconstruction with myocutaneous advancement flap from bilateral nasolabial and mentolabial fold. Operation result was performed histopathologic examination using frozen section technique. The results showed that the squamous cell carcinoma was poorly differentiated. Evaluation after surgery myocutaneous flap was merged well, no sign of inflammation nor infection. Patient could open his mouth, eat, drink, and talk without any complaint. Patient was then performed routinely chemoradiotherapy two weeks after surgery.

\section{REFERENCES}

Cook JL (2013). The reconstruction of two large fullthickness wound of the upper lip with different operative techniques: when possible, a local flap repair is preferable to reconstruct with free tissue transfer. American society for dermatologic surgery. Spain: Wiley periodicals, Inc. Available from: http://onlinelibrary.wiley.com.scihub.cc/doi/10.1111/d su.12033/pdf\# Accessed at February 10, 2017

Fernandez R (2015). Lip reconstruction. In: Fernandez, ed. 1st ed. Local and regional flaps in head and neck reconstruction: a practical approach. Oxford, Jon Wiley and sons, p 186-205

Marcos JAG, Rincon IH, Corcoles CG, Alfaro MS, Martinez EP, Rodriguez SA (2014). Bilateral reverse yu flap for upper lip reconstruction after oncologic resection. American society for dermatologic surgery. Spain, Wiley periodicals, Inc. Available from: https://www.ncbi.nlm.nih.gov/pubmed/23915230

Accessed March 13, 2017

Matros E, Pribaz JJ (2014). Reconstruction of acquired lip deformities. In: Thorne CH, ed. Grabb and Smith's plastic surgery. 7th Ed. Philadelphia, Lippincott Williams\&Wilkins, 372-83

Nishihara K, Nakasone T, Matayoshi A, Maruyama T, Arasaki A (2016). Upper lip reconstruction after oncologic resection by a sliding advancement cheek flap with buccal mucosal reversion. Departement of oral and maxillofacial surgery, University of Ryukyus hospital, Okinawa, Japan. Available from: http://journals.lww.com/prsgo/Fulltext/2016/11000/U pper_Lip_Reconstruction_after_Oncologic_Resection. 34.aspx Accessed February 8, 2017

Oseni OG, Fadare AE, Majaro MO, Olaitan PB (2015). Total reconstruction of the upper lip using bilateral nasolabial flaps, submental flap, and mucosal graft following complete resection for squamous cell carcinoma. Hindawi publishing corporation. Available from: https://www.hindawi.com/journals/cris/2015/ 782151. Accessed February 8, 2017

Puscas L, Fritz MA, Esclamado RM (2014). Lip cancer. In: Johnson JT, Rosen CA, eds. Bailey's head and neck surgery-otolaryngology. 5th Ed. Philadelphia, Lippincott Williams \&Wilkins, p 1788-1804

Salibian A, Urken AL (2014). Reconstruction of the lips. In: Urken ML, ed. Multidisciplinary head and neck reconstruction. A defect-oriented approach. Philadelphia, Lippincott Williams\&Wilkins, p 83-132

Weerda H (2001). The lips. In: Weerda H, ed. Reconstructive facial plastic surgery. Illinois, Thieme, p 56-67 